\title{
Effects of zinc supplementation and zinc chelation on in vitro $\beta$-cell function in INS-1E cells
}

\author{
Sanne Bjørn Nygaard*, Agnete Larsen, Astrid Knuhtsen, Jørgen Rungby and Kamille Smidt
}

\begin{abstract}
Background: Zinc is essential for the activities of pancreatic $\beta$-cells, especially insulin storage and secretion. Insulin secretion leads to co-release of zinc which contributes to the paracrine communication in the pancreatic islets. Zinc-transporting proteins (zinc-regulated transporter, iron-regulated transporter-like proteins [ZIPs] and zinc transporters [ZnTs]) and metal-buffering proteins (metallothioneins, MTs) tightly regulate intracellular zinc homeostasis. The present study investigated how modulation of cellular zinc availability affects $\beta$-cell function using INS-1E cells.

Results: Using INS-1E cells, we found that zinc supplementation and zinc chelation had significant effects on insulin content and insulin secretion. Supplemental zinc within the physiological concentration range induced insulin secretion. Insulin content was reduced by zinc chelation with $N, N, N$, N-tektrakis(2-pyridylmethyl)-ethylenediamine. The changes in intracellular insulin content following exposure to various concentrations of zinc were reflected by changes in the expression patterns of MT-1A, ZnT-8, ZnT-5, and ZnT-3. Furthermore, high zinc concentrations induced cell necrosis while zinc chelation induced apoptosis. Finally, cell proliferation was sensitive to changes in zinc the concentration.

Conclusion: These results indicate that the $\beta$-cell-like function and survival of INS-1E cells are dependent on the surrounding zinc concentrations. Our results suggest that regulation of zinc homeostasis could represent a pharmacological target.
\end{abstract}

Keywords: Zinc, Insulin, Zinc transporter, Metallothionein, Chelation, TPEN, INS-1E cells, $\beta$-cell, Diabetes

\section{Background}

Pancreatic tissue has high zinc $\left(\mathrm{Zn}^{2+}\right)$ concentrations relative to other tissues because zinc is essential for its exocrine and endocrine functions [1]. In particular, $\mathrm{Zn}^{2+}$ is needed for the correct storage of insulin in secretory vesicles by ensuring that insulin forms crystalline structures [2]. Furthermore, $\mathrm{Zn}^{2+}$ is co-secreted with insulin and is involved in paracrine and autocrine communication within the pancreas [3]. Finally, $\mathrm{Zn}^{2+}$ regulates the activity of ATP-sensitive potassium $\left(\mathrm{K}_{\mathrm{ATP}}\right)$ channels and calcium $\left(\mathrm{Ca}^{2+}\right)$ channels, which are involved in glucoseinduced insulin secretion $[4,5]$.

Abnormal zinc homeostasis seems to play an important role in impaired insulin sensitivity and diabetes. Diabetic subjects often display hypozincemia and hyperzincuria [6,7], and zinc deficient rats exhibit reduced insulin secretion and glucose sensitivity [8]. A local

\footnotetext{
* Correspondence: sbn@farm.au.dk
Department of Biomedicine, Centre of Pharmacology and Pharmacotherapy,

* Correspondence: sbn@farm.au.dk Health, Aarhus University, Wilhelm Meyers Allé 4, Bld 1240, 8000 Aarhus, Health, Aarh
}

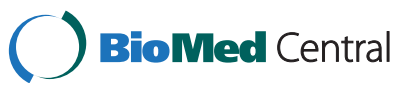

(C) 2014 Nygaard et al.; licensee BioMed Central Ltd. This is an open access article distributed under the terms of the Creative Commons Attribution License (http://creativecommons.org/licenses/by/2.0), which permits unrestricted use, distribution, and reproduction in any medium, provided the original work is properly cited. in $\mathrm{Zn}^{2+}$ concentrations cause pancreatic cell by inducing apoptosis [9], while reductions in free zinc are associated with decreased insulin content in $\beta$ cells $[10,11]$.

Cellular zinc homeostasis is tightly regulated because of the regulatory roles of intracellular $\mathrm{Zn}^{2+}$. Specialized proteins are responsible for controlling zinc import and export, as well as its intracellular distribution. Two classes of metal carrier proteins control the transmembrane transport of zinc ions. Zinc-regulated transporters and iron-regulated transporter-like proteins (ZIPs) facilitate $\mathrm{Zn}^{2+}$ influx into the cell and zinc transporters (ZnTs) facilitate $\mathrm{Zn}^{2+}$ efflux out of the cell $[12,13]$. The free zinc concentration is also influenced by the buffering activities of metallothioneins (MTs). MTs are a family of metal-binding proteins that are thought to maintain a reservoir of $\mathrm{Zn}^{2+}$ for use in cellular activities while simultaneously protecting against zinc toxicity $[14,15]$. Paradoxically, zinc supplementation and zinc depletion can be cytotoxic [16-20]. 
Modifying intracellular $\mathrm{Zn}^{2+}$ traffic by changing the gene expression levels of specific $\mathrm{ZnT}$ genes also affects $\beta$-cell insulin content and secretion [11,21-23]. The gene transcription of ZnTs and MTs is thought to be regulated by the intracellular zinc concentration, as demonstrated by studies using pancreatic islets, other cell lines (e.g., Caco-2 and HT-29 cells), and in some subsets of leukocytes [11,16-20,24,25]. Polymorphisms in the ZnT8 gene are associated with glucose intolerance and type 2 diabetes [26-29]. Furthermore, streptozotocin (STZ)treated ZnT-3-knockout mice exhibit impaired glucose metabolism compared with STZ-treated wild-type mice [11]. Overexpression of MTs was reported to prevent STZ-induced islet disruption, delay the onset of hyperglycemia in STZ-treated mice, and improve islet $\beta$-cell survival [30-32]. Finally, polymorphisms in genes encoding different isoforms of MTs were reported to be associated with the development of type 2 diabetes and diabetic complications [33,34].

Despite intensive research, the full consequence of altered zinc bioavailability on $\beta$-cell function remains unclear. Therefore, the present study investigated how cell survival, insulin content/secretion, and the expression of specific $\beta$-cell-relevant ZnTs and MTs respond to changes in the zinc environment following supplementation or chelation of zinc. We found that zinc-specific interventions had significant effects on the $\beta$-cell-like activity of INS-E1 cells, demonstrating the pharmacological potential of zinc supplementation or chelation.

\section{Methods}

\section{Cell culture}

Rat INS-1E cells were used in this in vitro study. The INS-1E cell line is an established glucose-sensitive cell line with $\beta$-cell-like activity $[35,36]$. INS-1E cells were cultured in a $\mathrm{CO}_{2}$ atmosphere in complete RPMI 1640 supplemented with $11 \mathrm{mM}$ glucose, 10\% $(v / v)$ heat-inactivated fetal bovine serum, $50 \mu \mathrm{M} \beta$ mercaptoethanol, $2 \mathrm{mM}$ L-glutamine, $100 \mathrm{U} / \mathrm{ml}$ penicillin, and $100 \mu \mathrm{g} / \mathrm{ml}$ streptomycin, as previously described $[10,11,21]$. The zinc concentration of this medium was approximately $2.5 \mu \mathrm{mol} / \mathrm{l}[10]$.

\section{Zinc supplementation and chelation}

For stimulation assays, cells were plated into six-well plates (NUNC) in complete RPMI 1640 supplemented with $11 \mathrm{mM}$ glucose, $10 \%(\mathrm{v} / \mathrm{v})$ heat-inactivated fetal bovine serum, $50 \mu \mathrm{M} \beta$-mercaptoethanol, $2 \mathrm{mM}$ L-glutamine, $100 \mathrm{U} / \mathrm{ml}$ penicillin, and $100 \mu \mathrm{g} / \mathrm{ml}$ streptomycin with the addition of either $5 \mu \mathrm{M}$ to $1 \mathrm{mM}$ zinc chloride $\left(\mathrm{ZnCl}_{2}\right)$ (Merck, Germany) or $2.5-50 \mu \mathrm{M}$ of the $\mathrm{Zn}^{2+}$ chelator $N, N, N, N$-Tektrakis(2-pyridylmethyl)-ethylenediamine (TPEN) (Sigma Aldrich, Denmark). The basal glucose concentration was kept permanently at $11 \mathrm{mM}$ because we experienced greater insulin response and cell replication of the INS-1E, and continuous growth at this concentration (unpublished data). We used 3-6 replicates for the analyses of mRNA expression, viability, DNA fragmentation assessment, and insulin measurements.

\section{Cell viability, cell cycle, and DNA fragmentation assay}

INS-1E cells were treated with $50 \mu \mathrm{M}$ to $1 \mathrm{mM} \mathrm{ZnCl}_{2}$ or 2.5-50 $\mu \mathrm{M}$ TPEN in complete RPMI medium for $24 \mathrm{~h}$. Cells were harvested by trypsinization and samples pooled with cells floating in the used cell culture medium. The cells were partly collected in RPMI medium for assessing viability and partly in PBS for cell cycle and DNA fragmentation assays. Before analyzing cell cycle status and DNA fragmentation, the cells were transferred to ice-cold 70\% ethanol, vortexed, and permeabilized at $0-4^{\circ} \mathrm{C}$ for $\geq 12 \mathrm{~h}$. Cell cycle and DNA fragmentation were determined by incubating permeabilized cells in $1 \mu \mathrm{g} / \mathrm{ml} \mathrm{4',6-diamidino-2-phenylindole}$ (DAPI) (Chemometec, Denmark), a DNA-specific dye, for $15 \mathrm{~min}$ at $37^{\circ} \mathrm{C}$ followed by fluorescence analysis on a NucleoCounter NC-3000 system (Chemometec). Viability was determined by analyzing cell samples on Via1Cassettes (Chemometec) coated with two different dyes to stain the entire cell population (acridine orange) and nonviable cells (DAPI).

\section{Insulin assay}

INS-1E cells were treated with $5 \mu \mathrm{M}$ to $1 \mathrm{mM} \mathrm{ZnCl}_{2}$ or 2.5-50 $\mu \mathrm{M}$ TPEN in complete RPMI medium for $24 \mathrm{~h}$. The cells were then incubated for $2 \mathrm{~h}$ in serum-free Krebs-Ringer bicarbonate HEPES buffer at $\mathrm{pH} 7.4$ containing $115 \mathrm{mM} \mathrm{NaCl}, 4.7 \mathrm{mM} \mathrm{KCl}, 1.2 \mathrm{mM} \mathrm{MgSO}_{4}$, $2.6 \mathrm{mM} \mathrm{CaCl}_{2}, 1.2 \mathrm{mM} \mathrm{KH_{2 }} \mathrm{PO}_{4}, 20 \mathrm{mM}$ HEPES, $5 \mathrm{mM}$ $\mathrm{NaHCO}_{3}, 0.1 \%(v / v)$ human serum albumin (Sigma), with or without $50 \mu \mathrm{M}$ to $1 \mathrm{mM} \mathrm{ZnCl}_{2}$ or $2.5-50 \mu \mathrm{M}$ TPEN and $11 \mathrm{mM}$ glucose. The incubation medium was collected to measure insulin secretion. The cells were collected in Earle's basal medium (Invitrogen, Denmark) by scraping followed by centrifugation. Half of the intact cells from each sample were re-suspended in a buffer comprising $0.75 \%(v / v)$ glycine and $0.25 \%(v / v)$ bovine serum albumin at $\mathrm{pH} 8.8$ to measure the insulin concentration, or in $0.1 \% \mathrm{M} \mathrm{NaOH}$ to measure the protein concentration. The total protein concentration was measured using a BCA Protein Assay Reagent Kit from Pierce, USA (Bie \& Berntsen A/S, Denmark). The insulin concentration was determined using an ultrasensitive rat insulin enzyme-linked immunosorbent assay kit from DRG Diagnostics (VWR, Denmark).

\section{RNA extraction and cDNA synthesis}

INS-1E cells were treated with $5 \mu \mathrm{M}$ to $1 \mathrm{mM} \mathrm{ZnCl}_{2}$ or 2.5-50 $\mu \mathrm{M}$ TPEN in complete RPMI medium for $24 \mathrm{~h}$. 
It was not possible to collect RNA material from cells treated with $50 \mu \mathrm{M}$ TPEN most likely due to severe toxicity of TPEN at this concentration level. RNA was extracted using the RNeasy Mini Kit Qiagen (VWR) and treated with DNase (VWR). cDNA was synthesized from total RNA using an ImProm- $\mathrm{II}^{\text {mit }}$ Reverse transcription system (Promega, Denmark).

\section{Real-time PCR}

Quantitative real-time PCR was performed in duplicate using IQ Sybr Green supermix (Bio-Rad, Denmark) in a MyiQ Two-Color Real-time PCR detection system (BioRad). A melting curve was prepared for all reactions. The results were analyzed with $\mathrm{iQ}^{\mathrm{TM}_{5}}$ Optical System Software, Version 2.1. Starting quantities were calculated from a standard curve. For each experiment, the most stable housekeeping genes were found using the method described by Vandesompele et al. [37]. Expression levels were normalized to the three most stable housekeeping genes from the following: $\beta$-actin, cyclophilin-A (CycA), heat shock protein (HSP), clathrin (Cltc), and ubiquitinconjugase-7 (UBC-7). We selected the most stable housekeeping genes and normalized the data using previously reported methods $[37,38]$.

\section{Primers used for real-time PCR}

The following (forward and reverse) primers were used: UBC-7, 5' -CAG CTG GCA GAA CTC AAC AA-3' and 5'-TTT GGG TGC CAA ATC TCT GT-3' (annealing temperature $58^{\circ} \mathrm{C}$ ); Cltc, $5^{\prime}$-AAG GAG GCG AAA CTC ACA GA-3' and 5'-GAG CAG TCA ACA TCC AGC AA-3' (annealing temperature $59^{\circ} \mathrm{C}$ ); HSP, $5^{\prime}$-GAT TGA CAT CAT CCC CAA CC-3' and 5'-CTG CTC ATC ATC GTT GTG CT-3' (annealing temperature $59^{\circ} \mathrm{C}$ ); CycA, 5'-AGG TCC TGG CAT CTT GTC CA-3' and 5'-CTT GCT GGT CTT GCC ATT CC-3' (annealing temperature $\left.58^{\circ} \mathrm{C}\right) ; \beta$-actin, $5^{\prime}$-CTA CAA TGA GCT GCG TGT GGC $3{ }^{\prime}$ and $5^{\prime}$-ATC CAG ACG CAG GAT GGC ATG-3' (annealing temperature $62^{\circ} \mathrm{C}$ ); Bax, $5^{\prime}$ GTG AGC GGC TGC TTG TCT-3' and $5^{\prime}$-GTG GGG GTC CCG AAG TAG-3' (annealing temperature $59^{\circ} \mathrm{C}$ ); Bcl-2, 5'-CGA CTT TGC AGA GAT GTC CA-3' and 5'-ATG CCG GTC AGG TAC TCA G-3' (annealing temperature $57^{\circ} \mathrm{C}$ ); insulin, $5^{\prime}$-CGC TTC CTG CCC CTG CTG GC-3' and 5'-CGG GCC TCC ACC CAG CTG CTC CA-3' (annealing temperature $67^{\circ} \mathrm{C}$ ); ZnT-3, 5'-TCC TCT TCT CTA TCT GCG CCC-3' and 5'TGT GCG GAG GCA ACG TGG TAA-3' (annealing temperature $59^{\circ} \mathrm{C}$ ); ZnT-5, 5'-TCC ACA TGC TCT TTG ACT GC-3' and $5^{\prime}$-GTC AAG TTC CGG AGG ATC AA-3' (annealing temperature $64^{\circ} \mathrm{C}$ ); ZnT-8, $5^{\prime}$ GGT GGA CAT GTT GCT GGG AG-3' and 5'-CAC CAG TCA CCA CCC AGA TG-3' (annealing temperature $56^{\circ} \mathrm{C}$ ); MT-1A, $5^{\prime}$-TCC CGA CTT CAG
CAG CCC GA-3' and 5'-GCC CTG GGC ACA TTT GGA GC-3' (annealing temperature $63^{\circ} \mathrm{C}$ ); and MT-3, 5'-TGG TTC CTG CAC CTG CTC GG-3' and 5' -CAC CAG GGA CAC GCA GCA CT-3' (annealing temperature $63^{\circ} \mathrm{C}$ ).

\section{Statistical analysis}

Data are presented as mean values with the standard error of the mean (SEM). One-way analysis of variance with Dunnett's multiple comparison test was used to determine statistical significance among groups. Values of $P<0.05$ were considered to indicate a significant difference between the experimental and control conditions.

\section{Results}

\section{High zinc concentrations reduce INS-1E cell viability}

The number of viable INS-1E cells decreased significantly when the $\mathrm{ZnCl}_{2}$ concentration reached $0.4 \mathrm{mM}$. The percentage of viable cells was decreased by $16.9 \%$ at $0.4 \mathrm{mM} \mathrm{ZnCl}_{2}$ and only $47.1 \%$ of the cells were viable at the highest $\mathrm{ZnCl}_{2}$ concentration, $1.0 \mathrm{mM}$ (Figure 1A). Based on DNA fragmentation assays, treatment with $\mathrm{ZnCl}_{2}$ did not promote apoptosis (Figure 1A) and only a small increase in the Bax/Bcl-2 ratio was observed at $1.0 \mathrm{mM} \mathrm{ZnCl}_{2}$ (Figure 1B).

\section{Zinc chelation impairs INS-1E cell viability by inducing apoptosis}

The viability of INS-1E cells decreased significantly by $18.2 \%$ following exposure to $50 \mu \mathrm{M}$ TPEN (Figure 1C). DNA fragmentation was detected at $10 \mu \mathrm{M}$ TPEN. Severe DNA fragmentation was observed at $50 \mu \mathrm{M}$ TPEN and $41.4 \%$ of the cells exhibited reduced DNA content as a consequence of DNA fragmentation (Figure 1C). The Bax/Bcl-2 ratio was significantly increased in cells exposed to $10 \mu \mathrm{M}$ TPEN (Figure 1D).

\section{The INS-1E cell cycle is affected by zinc supplementation}

Supplementation with $\mathrm{ZnCl}_{2}$ disturbed the baseline distribution of cells in the different stages of the cell cycle (Figure 2A, B). Low $\mathrm{ZnCl}_{2}$ concentrations (0.05$0.4 \mathrm{mM}$ ) increased the proportion of cells in the $\mathrm{G} 2 / \mathrm{M}$ phase while higher $\mathrm{ZnCl}_{2}$ concentrations $(0.7-1.0 \mathrm{mM}$ ) reduced the number of cells in the G2/M phase. The fraction of cells in the $\mathrm{S}$ phase was also affected by the $\mathrm{ZnCl}_{2}$ concentration. The effect was particularly evident at $0.4 \mathrm{mM} \mathrm{ZnCl}_{2}$, where a two-fold increase in the number of cells was detected compared with the control cells (Figure 2A).

\section{Chelation of $\mathrm{Zn}^{2+}$ by TPEN reduces the proportion of dividing cells}

The ratio of cells in the $S$ phase was unaffected at all conditions tested, except in cells treated with $5.0 \mu \mathrm{M}$ 

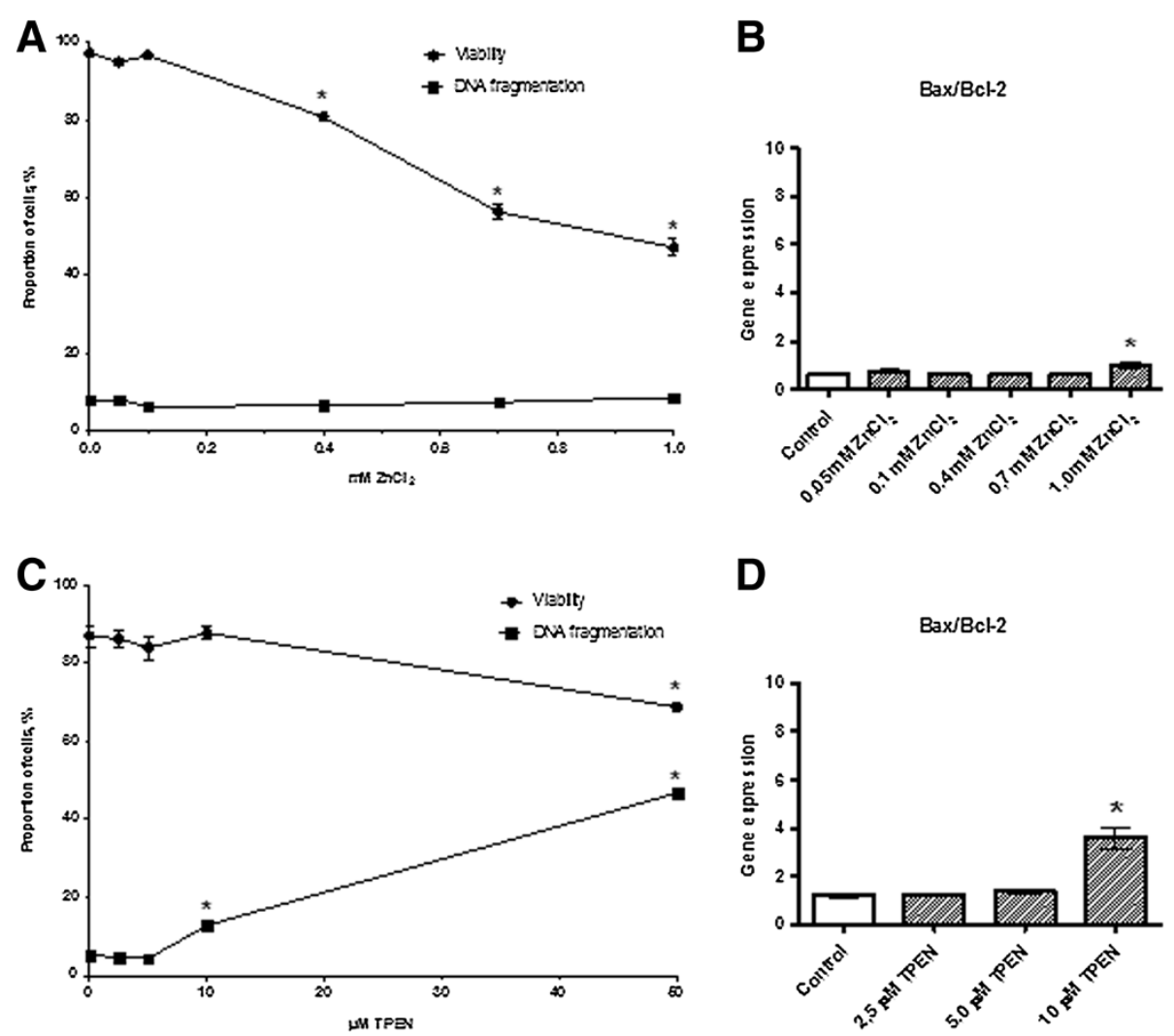

Figure 1 Cell survival. INS-1E cells were exposed to $\mathrm{ZnCl}_{2}$ (A, B) or TPEN (C, D) for $24 \mathrm{~h}$ in the presence of $11 \mathrm{mM}$ glucose. (A, C) cell viability and DNA fragmentation. (B, D) Bax/Bcl-2 gene expression. In cells exposed to $\mathrm{ZnCl}_{2}$, gene expression was normalized for $\beta$-actin, $\mathrm{HSP}$, and Cltc. In cells exposed to TPEN, gene expression was normalized for HSP, CyCA, and UBC-7. Data are shown as the mean \pm SEM $(n=4-6)$. ${ }^{* P}<0.05$.

TPEN, where the proportion of cells was significantly decreased (Figure $2 \mathrm{C}$ ). TPEN at concentrations $\geq 5.0 \mu \mathrm{M}$ reduced the proportion of actively dividing cells in the G2/M phase (Figure 2C).

Zinc is required to maintain baseline insulin secretion Insulin gene expression was significantly reduced following exposure to cytotoxic concentrations of $\mathrm{ZnCl}_{2}(0.4-$ $1.0 \mathrm{mM}$; Figure $3 \mathrm{~A}$ ). Although insulin content was unaffected by $\mathrm{ZnCl}_{2}$ (Figure 3B), the amount of secreted insulin was increased (Figure $3 \mathrm{C}$ ), resulting in a significant increase in zinc-induced insulin secretion/insulin content ratio (Figure 3D). In an additional experiment using physiological concentrations of zinc $(5-30 \mu \mathrm{M})$ we found no changes in the intracellular insulin content (Figure 4A). Insulin secretion increased in a dosedependent manner across the concentration range of 5-10 $\mu \mathrm{M} \mathrm{ZnCl}_{2}$ relative to the control group, and a plateau was reached at $15-30 \mu \mathrm{M} \mathrm{ZnCl}_{2}$ (Figure 4B). The insulin secretion/insulin content ratio at 5-15 $\mu \mathrm{M} \mathrm{ZnCl}{ }_{2}$ showed a similar pattern to the insulin secretion data (Figure 4C).
Chelation of zinc by TPEN decreases the intracellular insulin content in INS-1E cells

Zinc chelation with TPEN did not affect insulin gene expression (Figure 5A). However, the intracellular insulin content was significantly reduced following exposure to 5.0, 10, or $50 \mu \mathrm{M}$ TPEN (Figure 5B). Zinc chelation did not affect insulin release (Figure $5 \mathrm{C}$ ), resulting in an increase in the overall insulin secretion/insulin content ratio (Figure 5D).

\section{ZnT-3 gene expression is markedly upregulated by zinc supplementation}

$\mathrm{ZnCl}_{2}$ treatment significantly upregulated ZnT-3 transcriptions by $2-4.8$-fold at concentrations $\geq 0.4 \mathrm{mM}$ (Figure 6A). By contrast, $\mathrm{Zn}^{2+}$ chelation with $10 \mu \mathrm{M}$ TPEN downregulated $\mathrm{ZnT}$-3 gene expression (Figure 6B).

\section{ZnT-5 gene expression is downregulated by zinc} chelation

ZnT-5 gene expression was not affected by zinc supplementation (Figure 7A) whereas chelation at high doses 


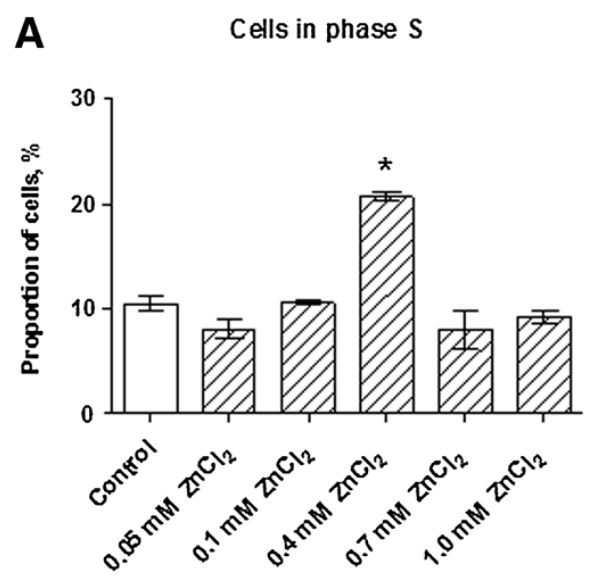

C

Cells in phase $\mathrm{S}$

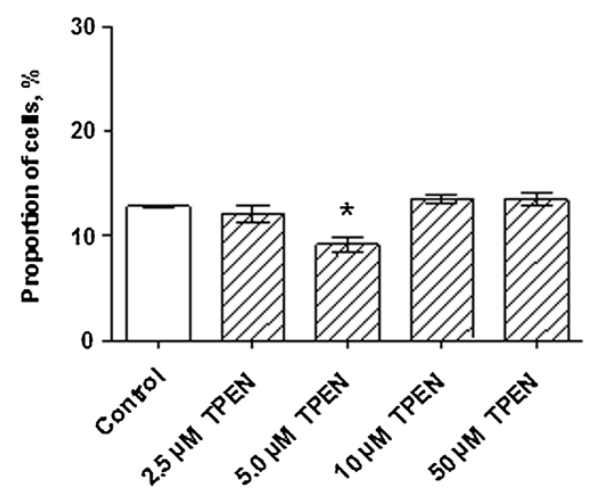

B Cells in the phases $\mathrm{G} 2$ and $\mathrm{M}$

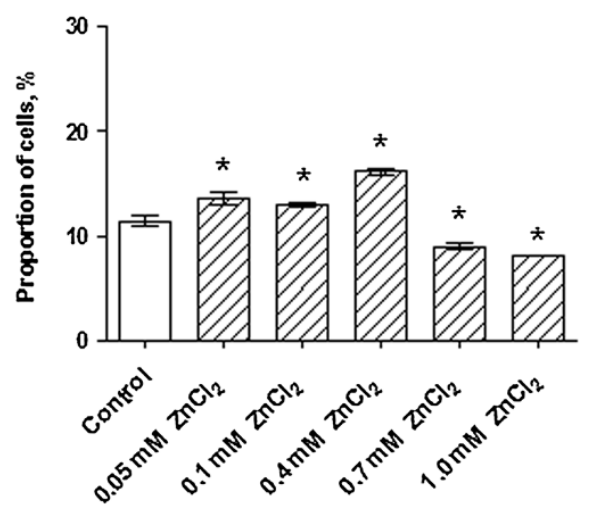

D Cells in the phases $\mathrm{G} 2$ and $M$

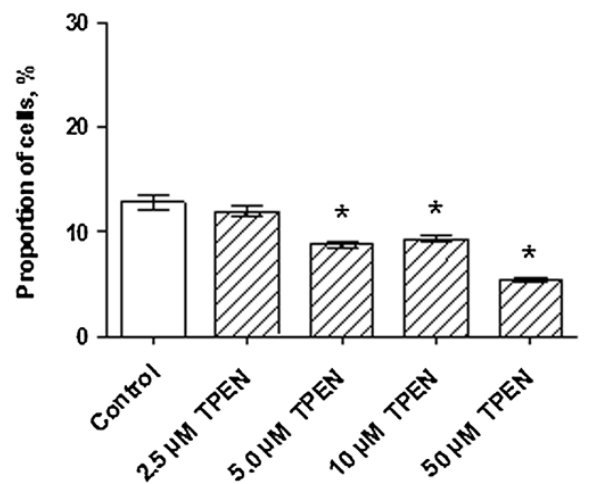

Figure 2 Cell cycle. The proportions of INS-1E cells in the $\mathrm{S}$ and G2/M phases were determined after exposure to $\mathrm{ZnCl} 2$ (A, B) or TPEN (C, D) for $24 \mathrm{~h}$ in the presence of $11 \mathrm{mM}$ glucose. Data are shown as the mean $\pm \operatorname{SEM}(n=4-6) .{ }^{*} P<0.05$.

(5.0 and $10 \mu \mathrm{M}$ ) of TPEN resulted in downregulation of ZnT-5 gene expression (Figure 7B).

\section{ZnT-8 gene expression is sensitive to zinc} supplementation and zinc chelation

ZnT-8 gene expression was gradually induced by zinc supplementation reaching statistical significance at $0.4 \mathrm{mM} \mathrm{ZnCl}_{2}$. The most cytotoxic $\mathrm{ZnCl}_{2}$ concentrations $(0.7-1.0 \mathrm{mM})$ markedly reduced the transcription of ZnT-8 (Figure 8A). ZnT-8 gene expression was significantly downregulated by chelation with $10 \mu \mathrm{M}$ TPEN (Figure 8B).

\section{MT-1A gene expression is upregulated by zinc supplementation without changes in MT-3}

The gene expression of MT-1A was exceptionally sensitive to $\mathrm{Zn}^{2+}$ supplementation resulting in a transcriptional upregulation, 100 to 300 -fold, at concentrations above $0.4 \mathrm{mM} \mathrm{ZnCl} 2$ (Figure 9A). By contrast, MT-3 transcription was only affected and was downregulated at the highest cytotoxic $\mathrm{ZnCl}_{2}$ concentration $(1.0 \mathrm{mM}$ $\mathrm{ZnCl}_{2}$; Figure 9B).
Zinc chelation by TPEN downregulates MT-1A gene expression

$\mathrm{Zn}^{2+}$ chelation with TPEN significantly downregulated MT-1A gene expression (Figure 10A) but did not affect MT-3 expression (Figure 10B).

\section{Discussion}

Using INS-1E cells, this study demonstrated that manipulation of the zinc environment may affect $\beta$-cell survival and insulin production by interfering with intracellular zinc homeostasis under the control of the zinc transporters ZnT-3, ZnT-5, and ZnT-8. Excess zinc supply seems to reduce the viability of INS-1E by causing cellular necrosis. Synaptic $\mathrm{Zn}^{2+}$ release was reported to be related to exocytotic neuronal death $[39,40]$. In this mechanism, zinc was reported to cause cell death by reentering neurons through $\mathrm{ZnTs}, \mathrm{N}$-methyl-D-aspartate receptor-mediator channels, and voltage-dependent calcium channels. Here, we find that zinc at concentrations of up to $0.1 \mathrm{mM} \mathrm{ZnCl}$ is well tolerated by INS-1E cells, but increasing the concentration from 0.2 to $1 \mathrm{mM}$ steadily increased cell death. At $1 \mathrm{mM} \mathrm{ZnCl}_{2}, 52.8 \%$ of 


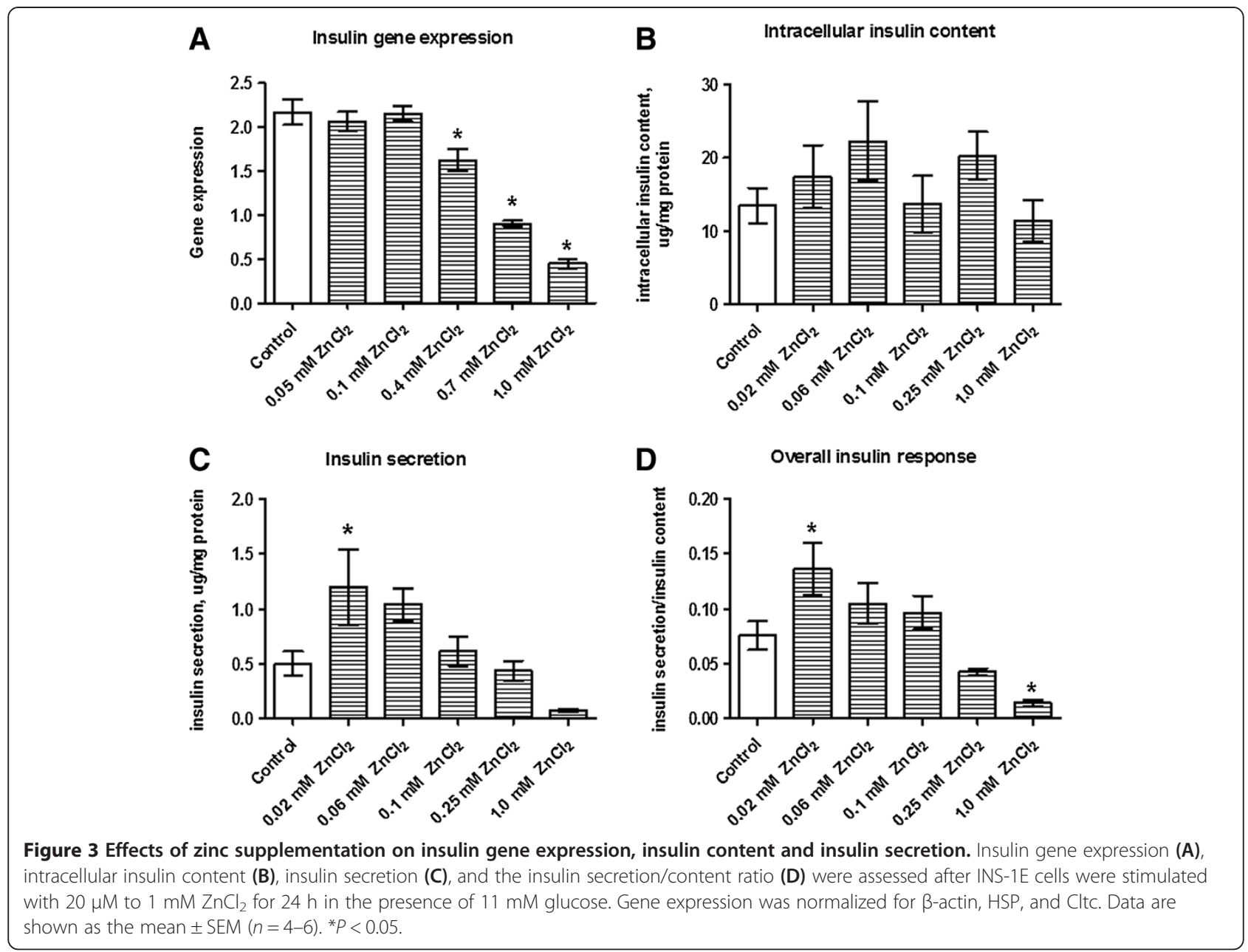

INS-1E cells were dead. The concentration of $\mathrm{Zn}^{2+}$ within the insulin granules is approximately $20 \mathrm{mM}$ $[40,41]$ and, upon glucose stimulation, the concentration of $\mathrm{Zn}^{2+}$ co-secreted into the extracellular space may reach $475 \mu \mathrm{M}$ [9], corresponding to the concentration of $400 \mu \mathrm{M}(0.4 \mathrm{mM})$ that significantly increased cell death in our study (Figure 1A). Our results indicate that an excessive extracellular $\mathrm{Zn}^{2+}$ load, resulting from insulin release, may promote $\beta$-cell death, which might be particularly important in the context of hyperinsulinemia. Reductions in $\mathrm{Zn}^{2+}$ packaging might also result in an increase in free labile zinc, increasing $\beta$-cell damage.

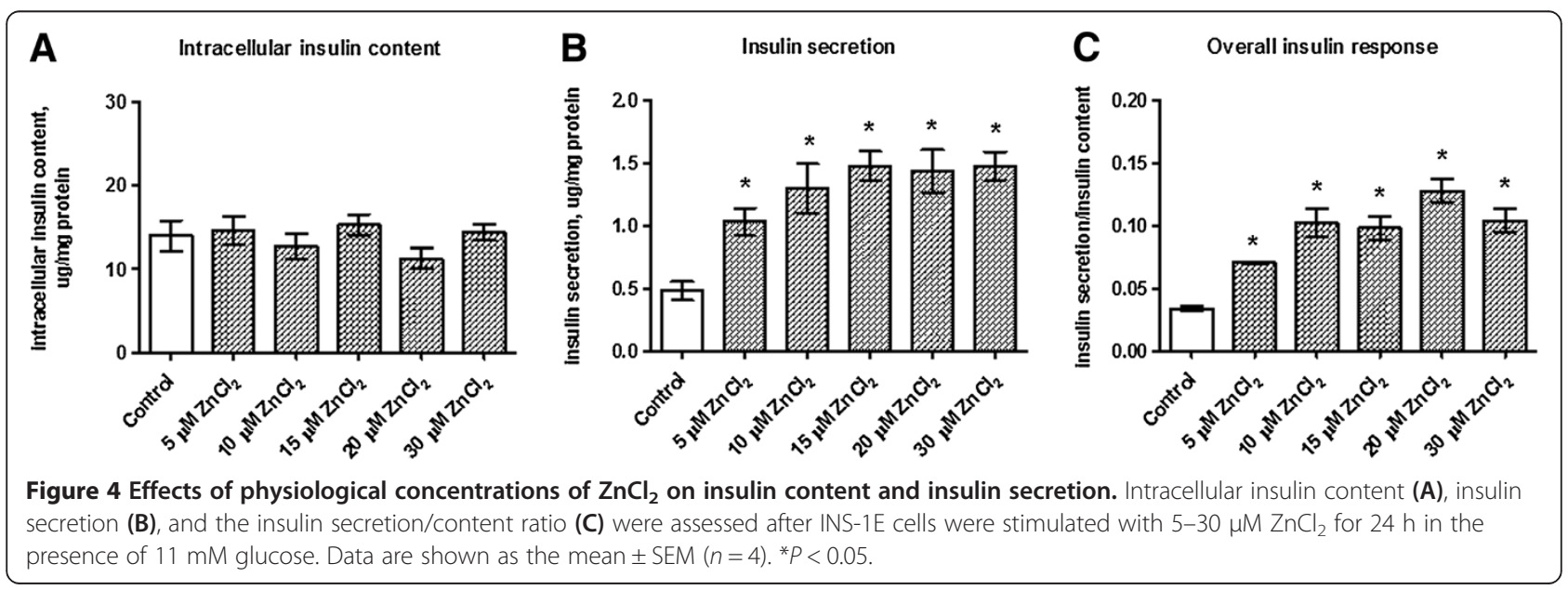



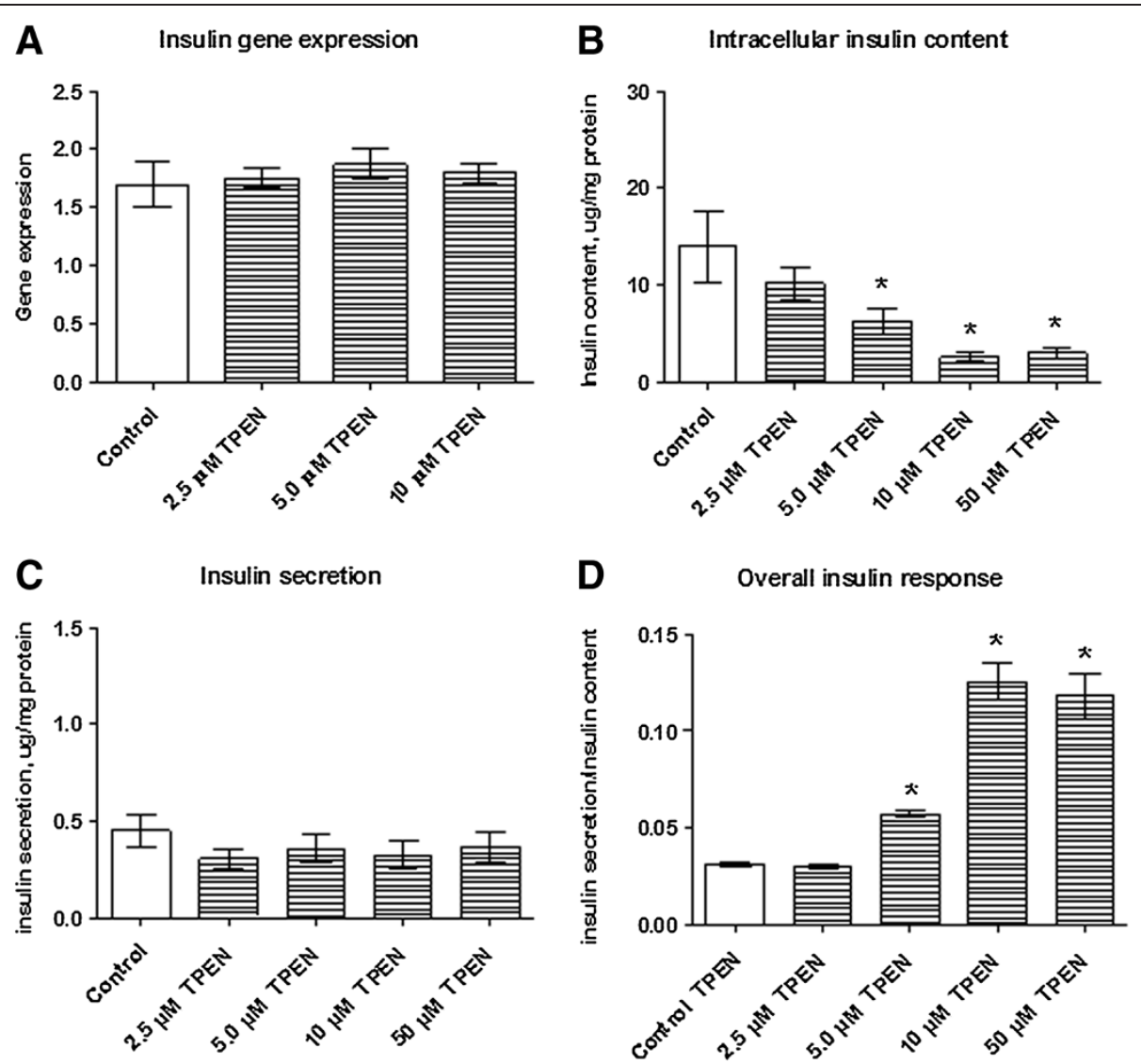

Figure 5 Effects of zinc chelation on insulin gene expression, insulin content and insulin secretion. Insulin gene expression (A), intracellular insulin content (B), insulin secretion (C), and the insulin secretion/content ratio (D) were assessed after INS-1E cells were stimulated with 2.5-50 $\mu \mathrm{M}$ TPEN for $24 \mathrm{~h}$ in the presence of $11 \mathrm{mM}$ glucose. Gene expression was normalized for HSP, CycA, and UBC-7. Data are shown as the mean $\pm \operatorname{SEM}(n=3-6) .{ }^{*} P<0.05$.

A similar cytotoxic effect might occur in autoimmune diabetes because an increase in secretory granular $\mathrm{Zn}^{2+}$ release occurs alongside the loss of $\beta$-cells [42-44]. Several studies have suggested that limiting cellular $\mathrm{Zn}^{2+}$ concentrations by reducing dietary zinc uptake or administering a low-affinity $\mathrm{Zn}^{2+}$ chelator, such as clioquinol, could attenuate the development of the diabetic state resulting from zinc accumulation [43,44].

MT-1A is abundantly expressed and is generally considered to have a protective role against oxidative stress.

A $\mathrm{ZnT}-3 \quad$ B

B ZnT-3
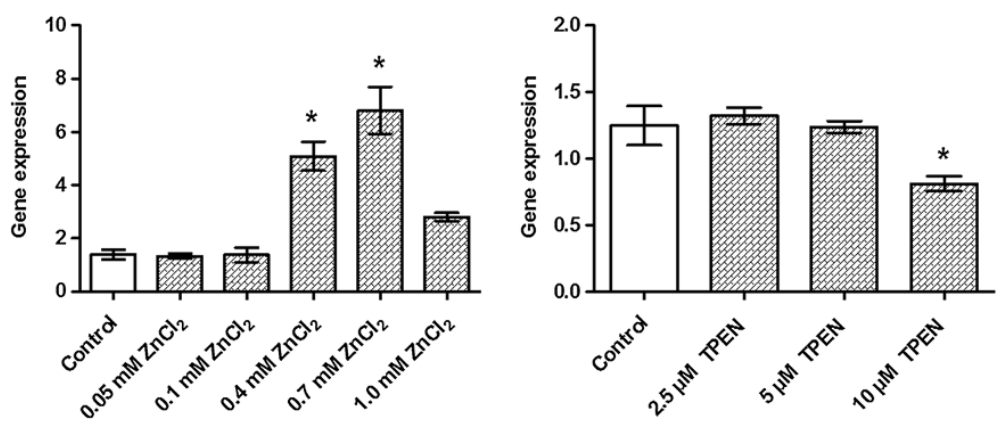

Figure 6 Effects of zinc supplementation and zinc chelation on the gene expression levels of ZnT-3. INS-1E cells were exposed to the indicated concentrations of $\mathrm{ZnCl}_{2}$ (A) or TPEN (B) for $24 \mathrm{~h}$ in the presence of $11 \mathrm{mM}$ glucose. The gene expression levels of ZnT-3 were normalized for $\beta$-actin, HSP, and Cltc in cells exposed to $\mathrm{ZnCl}_{2}$ and to HSP, CyCA, and UBC-7 in cells exposed to TPEN. Data are shown as the mean \pm SEM $(n=4-6) .{ }^{*} P<0.05$. 

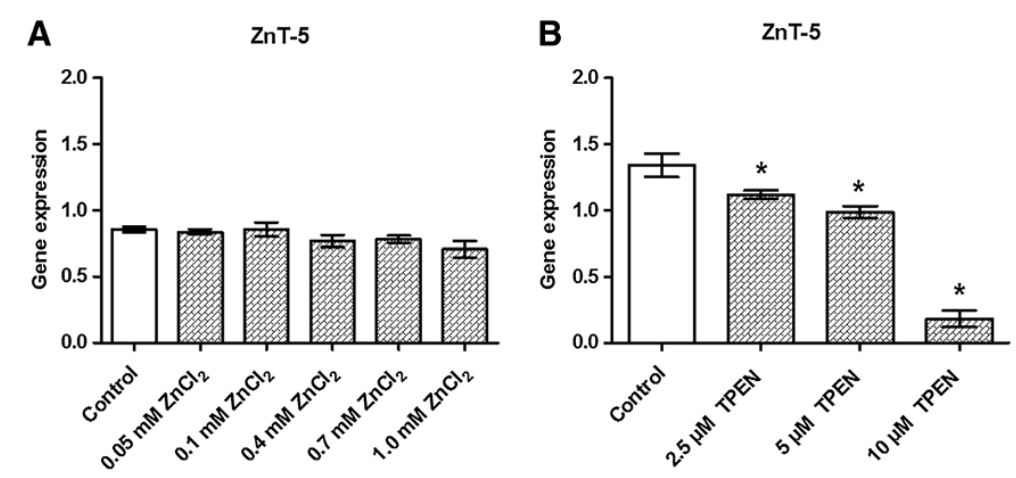

Figure 7 Effects of zinc supplementation and zinc chelation on the gene expression levels of ZnT-5. INS-1E cells were exposed to the indicated concentrations of $\mathrm{ZnCl}_{2}$ (A) or TPEN (B) for $24 \mathrm{~h}$ in the presence of $11 \mathrm{mM}$ glucose. The gene expression levels of ZnT-5 were normalized for $\beta$-actin, HSP, and Cltc in cells exposed to $\mathrm{ZnCl}_{2}$ and to HSP, CycA, and UBC-7 in cells exposed to TPEN. Data are shown as the mean $\pm \operatorname{SEM}(n=4-6) .{ }^{*} P<0.05$.

MT-1A is essential for the regulation of intracellular zinc homeostasis because it acts as a $\mathrm{Zn}^{2+}$ acceptor and a $\mathrm{Zn}^{2+}$ donor to control the availability of cellular zinc [45]. MT-1A gene expression is controlled by metal response element-binding transcriptional factor (MTF)-1 [46], allowing free $\mathrm{Zn}^{2+}$ to directly control the transcription of MT-1A. Notably, in the present study, we found that MT-1A responded strongly to changes in the zinc concentration. MT-1A upregulation was pronounced following zinc supplementation. Similar results were also observed in pancreatic islets $[18,24]$, indicating that excess extracellular zinc causes an increase in intracellular free $\mathrm{Zn}^{2+}$, a process that is possibly mediated by the ZnT-1 transporter.

MT-3 is predominately expressed in the brain, where it acts as a neuronal growth inhibition factor with neuroprotective properties [47]. Although MT-3 has been localized in peripheral tissues, its role in these tissues is not understood [14,48]. Unlike MT-1A, the expression of MT-3 does not seem to be controlled by MTF-1.
Consistent with this, we found that changes in the environmental $\mathrm{Zn}^{2+}$ concentration did not directly affect MT-3. However, we did observe transcriptional downregulation of MT-3 after exposing cells to highly cytotoxic conditions, such as $1.0 \mathrm{mM} \mathrm{ZnCl}_{2}$, and we expect this to be caused by the ongoing processes underlying cell death in these conditions. The results of this study support those of other studies indicating that MT-3 plays a different role to MT-1A in the pancreas, and that MT-3 is unlikely to be a direct regulator of intracellular zinc signaling in $\beta$-cells.

In neurons, ZnT-3 transports zinc ions into synaptic vesicles. This $\mathrm{Zn}^{2+}$ transporter is also expressed in $\beta$ cells $[11,14,49,50]$. The increase in ZnT-3 gene expression observed in the present study is consistent with our previous finding [11] that $\mathrm{ZnT}-3$ is upregulated during stressful conditions (Figure 6A).

Expression of ZnT-8 is highly tissue-specific and besides $\beta$-cells, $\mathrm{ZnT}-8$ is also expressed in adipose tissue and in the retina $[14,39,51]$. ZnT-8 is thought to be
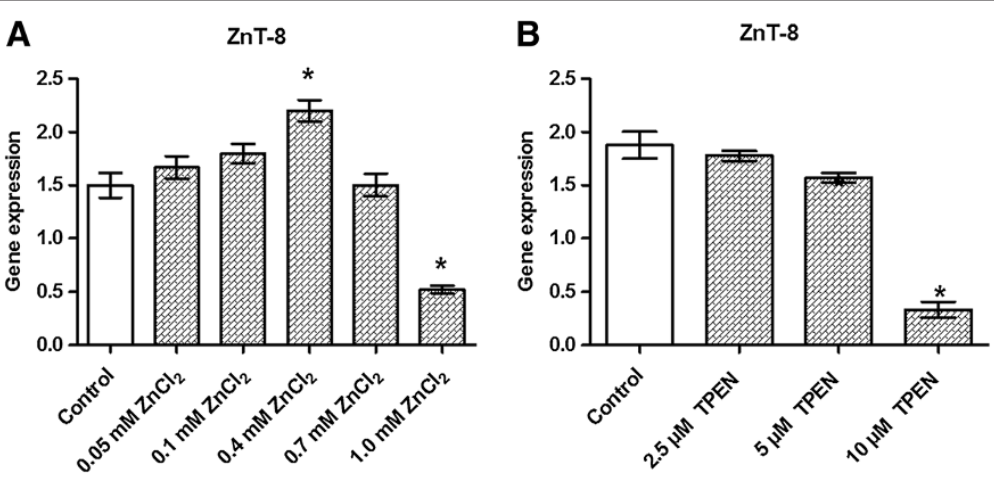

Figure 8 Effects of zinc supplementation and zinc chelation on the gene expression levels of ZnT-8. INS-1E cells were exposed to the indicated concentrations of $\mathrm{ZnCl}_{2}$ (A) or TPEN (B) for $24 \mathrm{~h}$ in the presence of $11 \mathrm{mM}$ glucose. The gene expression levels of ZnT-8 were normalized for $\beta$-actin, HSP, and Cltc in cells exposed to $\mathrm{ZnCl}_{2}$ and to HSP, CycA, and UBC-7 in cells exposed to TPEN. Data are shown as the mean \pm SEM $(n=4-6) .{ }^{*} P<0.05$. 

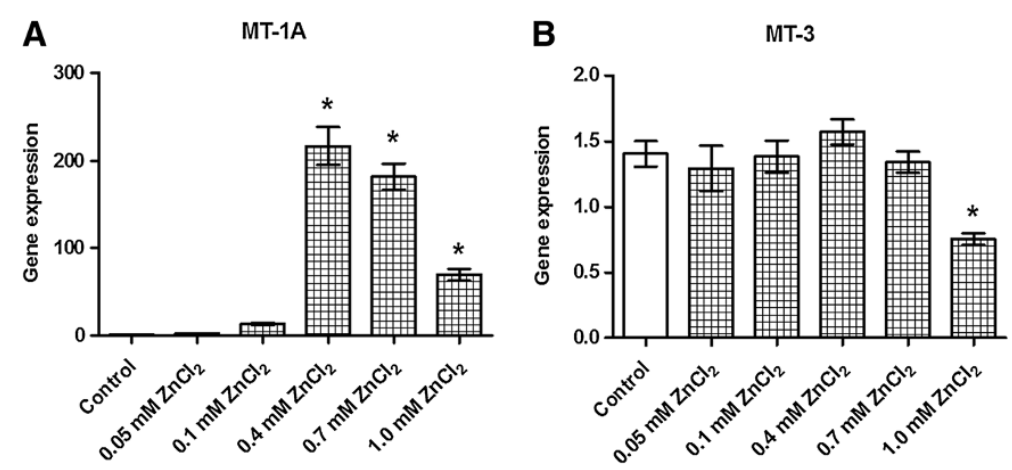

Figure 9 Effects of zinc supplementation on the gene expression levels of metallothioneins. INS-1E cells were exposed to the indicated concentrations of $\mathrm{ZnCl}_{2}$ for $24 \mathrm{~h}$ in the presence of $11 \mathrm{mM}$ glucose. The gene expression levels of MT-1A (A) and MT-3 (B) were normalized for $\beta$-actin, HSP, and Cltc. Data are shown as the mean \pm SEM $(n=4-6) .{ }^{*} P<0.05$.

crucial for $\beta$-cell function because it is thought to transport zinc ions into insulin-containing secretory vesicles $[23,52]$. Here, we found that ZnT-8 is upregulated by exposure to low, non-cytotoxic $\mathrm{ZnCl}_{2}$ concentrations, indicating that $\mathrm{Zn}^{2+}$ uptake into insulin-containing granules is increased if $\mathrm{Zn}^{2+}$ is readily available. This is supported by other findings showing that INS-1E cells overexpressing $\mathrm{ZnT}-8$ have higher intracellular $\mathrm{Zn}^{2+}$ concentrations compared with wild-type cells [21]. It is possible that this regulatory mechanism has a protective role because ZnT-8 overexpression was reported to protect $\beta$-cells from zinc depletion because of enhanced storage capacity [22]. It seems that $\mathrm{ZnT}-8$ gene expression is correlated with the cellular zinc content in $\beta$-cells, as observed in RPE cells [51]. At a functional level, the zinc supplementation study confirmed the importance of the constant presence of $\mathrm{Zn}^{2+}$ in controlling insulin secretion (Figure 4C). In this study, immediate insulin secretion was compared between a basal zinc environment and a $\mathrm{Zn}^{2+}$-supplemented environment. Overall, we found that zinc, at physiological concentrations $[1,53,54]$ of $15-30 \mu \mathrm{M}$, increased the release of insulin from INS-
$1 \mathrm{E}$ cells, emphasizing the importance of $\mathrm{Zn}^{2+}$ as a regulator of glucose-induced insulin secretion under normal conditions. This effect of zinc supplementation was demonstrated in a previous study using pancreatic islets, in which it was proposed that $\mathrm{Zn}^{2+}$ is an autocrine signaling molecule in the endocrine pancreas [55].

The pivotal role of $\mathrm{Zn}^{2+}$ in the regulation of insulin secretion is also reflected by the chelation experiments using TPEN. TPEN preferentially chelates free $\mathrm{Zn}^{2+}$, but also depletes zinc ions that are tightly bound to cellular metallo-proteins when administered at high concentrations. The effect of zinc chelation by TPEN on insulin secretion has not been examined in prior studies. We found that the predominant effect of chelation in INS$1 \mathrm{E}$ cells involves a reduction in the intracellular insulin content. Because insulin crystallization is an essential function of $\mathrm{Zn}^{2+}$, a reduction in intracellular insulin could be a consequence of impaired insulin storage in conditions of inadequate zinc. These results are consistent with our previous studies showing that the insulin content is reduced in $\beta$-cells exposed to the chelator diethyldithiocarbamate (DEDTC) [11].
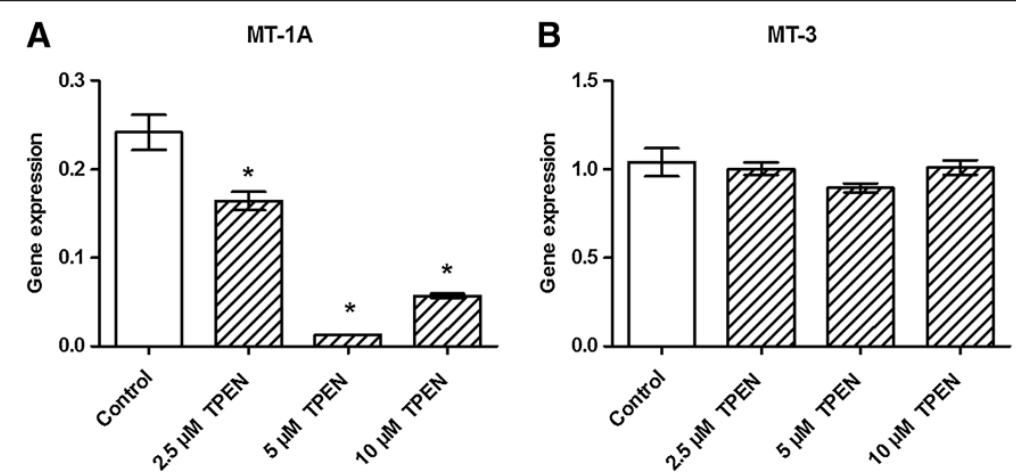

Figure 10 Effects of zinc chelation on the gene expression levels of metallothioneins. INS-1E cells were exposed to the indicated concentrations of $\mathrm{ZnCl}_{2}$ for $24 \mathrm{~h}$ in the presence of $11 \mathrm{mM}$ glucose. The gene expression levels of MT-1A (A) and MT-3 (B) were normalized for HSP, CyCA and UBC-7. Data are shown as the mean \pm SEM $(n=4-6) .{ }^{*} P<0.05$. 
ZnT-8 gene expression was reported to be downregulated by the chelator DEDTC [11,38], although this effect was less pronounced in the present study. The effects of zinc chelation by TPEN and DEDTC have been investigated in the context of hippocampal excitability. In the hippocampus, TPEN and DEDTC had different effects, suggesting that the discrepancy is caused by the more specific $\mathrm{Zn}^{2+}$ binding by TPEN than DEDTC, and by the fact that DEDTC chelates other metals, including copper [56]. In addition, TPEN may favor $\mathrm{Zn}^{2+}$ because TPEN has a higher binding affinity for $\mathrm{Zn}^{2+}$ (dissociation constant $1-2.6 \times 10^{-16} \mathrm{M}$ ) than for other metals [57].

TPEN-based $\mathrm{Zn}^{2+}$ chelation also reduced the viability of INS-1E cells. Administered in vitro, TPEN can chelate extracellular zinc ions, cytoplasmic-free $\mathrm{Zn}^{2+}$, zinc located within intracellular compartments, and strip $\mathrm{Zn}^{2+}$ from proteins [58]. Thus, exposing $\beta$-cells to TPEN is expected to reduce the availability of zinc and interfere with zinc-dependent cellular activities. DNA fragmentation assays showed that chelation is stressful to INS-1E cells, and initiates programmed cell death, even though Bax/Bcl-2 activity was unaffected after $24 \mathrm{~h}$ of stimulation, except at the most cytotoxic stimuli (Figure 1D). Monitoring $\mathrm{Bax} / \mathrm{Bcl}-2$ at an earlier time might have revealed an altered ratio. The pro-apoptotic effects of zinc deficiency were previously demonstrated in several other cell lines $[16,22,25,59,60]$. TPEN directly affected the distribution of cells in different stages of the cell cycle, reflecting the importance of $\mathrm{Zn}^{2+}$ in cell division. It seems likely that $\mathrm{Zn}^{2+}$ is required for the passage of cells through the cell cycle. Certainly, several DNAsynthesizing enzymes seem to depend on $\mathrm{Zn}^{2+}$, suggesting that zinc depletion suppresses DNA synthesis $[61,62]$.

Unlike other zinc transporters, ZnT-5 holds a unique position in regulating intracellular $\mathrm{Zn}^{2+}$ concentrations because it is localized in the Golgi apparatus, secretory vesicles, and in the cell membrane $[63,64]$. ZnT-5 is also implicated in $\mathrm{Zn}^{2+}$ efflux and influx. A study of $\mathrm{ZnT}-5-$ knockout mice revealed a reduction in islet zinc content in these animals [43]. Although the protein is abundant in pancreatic tissue [65], little is known about the function of ZnT-5 in this organ. In our experiments, ZnT-5 gene expression was not substantially affected by zinc supplementation but was sensitive to chelation by TPEN. This downregulatory effect of TPEN on ZnT-5 gene expression differs from that of studies using other cell types. ZnT-5 was reported to be upregulated by TPEN in Hela epithelial cells [25] and was upregulated or unaffected by TPEN in some subtypes of leukocytes [17]. Thus, the role of $\mathrm{ZnT}-5$ in cellular $\mathrm{Zn}^{2+}$ homeostasis may be tissue-specific and might be related to the role of free $\mathrm{Zn}^{2+}$ in individual cell types.

\section{Conclusion}

Using INS-1E cells, the present results indicate that $\beta$ cell function is directly related to the surrounding $\mathrm{Zn}^{2+}$ concentration, adding to the accumulating evidence that links abnormal zinc homeostasis to the development of diabetes. Manipulation of the cellular zinc environment was found to have significant effects on cell survival, cell proliferation, and insulin processing and release. Understanding the finely tuned system involved in zinc transport and zinc buffering might open a new field of research into pharmacological intervention aimed at prolonging and improving pancreatic $\beta$-cell function.

Competing interests

The authors declare that they have no competing interests.

\section{Authors' contributions}

$\mathrm{SBN}, \mathrm{AL}, J \mathrm{R}$, and $\mathrm{KS}$ conceived and designed the experiments, and wrote the manuscript. SBN and AK carried out the experiments. SBN, AL, AK, JR, and KS analyzed the data and approved the final version to be published. All authors read and approved the final manuscript.

\section{Acknowledgments}

The authors thank E. Cartsensen for her help with cell culture and insulin assays and K. Skjødt for her help with the Q-PCR. The INS-1E cells were kindly provided by Prof. CB Wollheim and Dr. Maehlen.

Received: 11 April 2013 Accepted: 4 February 2014

Published: 7 February 2014

\section{References}

1. Vallee $\mathrm{BL}$, Falchuk KH: The biochemical basis of zinc physiology. Physiol Rev 1993, 73(1):79-118.

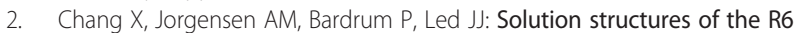
human insulin hexamer. Biochemistry 1997, 36(31):9409-9422.

3. Emdin SO, Dodson GG, Cutfield JM, Cutfield SM: Role of zinc in insulin biosynthesis. Some possible zinc-insulin interactions in the pancreatic B-cell. Diabetologia 1980, 19(3):174-182.

4. Hershfinkel M, Moran A, Grossman N, Sekler I: A zinc-sensing receptor triggers the release of intracellular $\mathrm{Ca} 2+$ and regulates ion transport. Proc Natl Acad Sci U S A 2001, 98(20):11749-11754.

5. Prost AL, Bloc A, Hussy N, Derand R, Vivaudou M: Zinc is both an intracellular and extracellular regulator of KATP channel function. J Physiol 2004, 559(Pt 1):157-167.

6. Kinlaw WB, Levine AS, Morley JE, Silvis SE, McClain CJ: Abnormal zinc metabolism in type II diabetes mellitus. Am J Med 1983, 75(2):273-277.

7. Chausmer AB: Zinc, insulin and diabetes. J Am Coll Nutr 1998, 17(2):109-115.

8. Quarterman J, Mills C, Humphries W: The reduced secretion of sensitivity to insulin in zinc deficient rats. BBRC 1966, 25:354-358.

9. Kim BJ, Kim YH, Kim S, Kim JW, Koh JY, Oh SH, Lee MK, Kim KW, Lee MS: Zinc as a paracrine effector in pancreatic islet cell death. Diabetes 2000, 49(3):367-372.

10. Sondergaard LG, Stoltenberg M, Flyvbjerg A, Brock B, Schmitz O, Danscher G, Rungby J: Zinc ions in beta-cells of obese, insulin-resistant, and type 2 diabetic rats traced by autometallography. APMIS 2003, 111(12):1147-1154.

11. Smidt $K$, Jessen $N$, Petersen $A B$, Larsen $A$, Magnusson $N$, Jeppesen JB, Stoltenberg M, Culvenor JG, Tsatsanis A, Brock B, et al: SLC30A3 responds to glucose- and zinc variations in beta-cells and is critical for insulin production and in vivo glucose-metabolism during beta-cell stress. Plos One 2009, 4(5):e5684.

12. Quraishi I, Collins S, Pestaner JP, Harris T, Bagasra O: Role of zinc and zinc transporters in the molecular pathogenesis of diabetes mellitus. Med Hypotheses 2005, 65(5):887-892.

13. Cousins RJ, Liuzzi JP, Lichten LA: Mammalian zinc transport, trafficking, and signals. J Biol Chem 2006, 281(34):24085-24089.

14. Mocchegiani E, Giacconi R, Malavolta M: Zinc signalling and subcellular distribution: emerging targets in type 2 diabetes. Trends Mol Med 2008, 14(10):419-428. 
15. Vasak M, Meloni G: Chemistry and biology of mammalian metallothioneins. J Biol Inorg Chem 2011, 16(7):1067-1078.

16. Shen H, Qin H, Guo J: Cooperation of metallothionein and zinc transporters for regulating zinc homeostasis in human intestinal Caco-2 cells. Nutr Res (New York, NY) 2008, 28(6):406-413.

17. Overbeck S, Uciechowski P, Ackland ML, Ford D, Rink L: Intracellular zinc homeostasis in leukocyte subsets is regulated by different expression of zinc exporters ZnT-1 to ZnT-9. J Leukoc Biol 2008, 83(2):368-380.

18. Ohly P, Dohle C, Abel J, Seissler J, Gleichmann H: Zinc sulphate induces metallothionein in pancreatic islets of mice and protects against diabetes induced by multiple low doses of streptozotocin. Diabetologia 2000, 43(8):1020-1030

19. Kindermann B, Doring F, Pfaffl $M$, Daniel H: Identification of genes responsive to intracellular zinc depletion in the human colon adenocarcinoma cell line HT-29. J Nutr 2004, 134(1):57-62.

20. Cao J, Bobo JA, Liuzzi JP, Cousins RJ: Effects of intracellular zinc depletion on metallothionein and ZIP2 transporter expression and apoptosis. J Leukoc Biol 2001, 70(4):559-566

21. Petersen AB, Smidt K, Magnusson NE, Moore F, Egefjord L, Rungby J: siRNA-mediated knock-down of ZnT3 and ZnT8 affects production and secretion of insulin and apoptosis in INS-1E cells. APMIS 2011, 119(2):93-102

22. Chimienti F, Devergnas S, Pattou F, Schuit F, Garcia-Cuenca R, Vandewalle B, Kerr-Conte J, Van Lommel L, Grunwald D, Favier A, et al: In vivo expression and functional characterization of the zinc transporter ZnT8 in glucose-induced insulin secretion. J Cell Sci 2006, 119(Pt 20):4199-4206.

23. Wijesekara N, Dai FF, Hardy AB, Giglou PR, Bhattacharjee A, Koshkin V, Chimienti F, Gaisano HY, Rutter GA, Wheeler MB: Beta cell-specific Znt8 deletion in mice causes marked defects in insulin processing, crystallisation and secretion. Diabetologia 2010, 53(8):1656-1668.

24. Bellomo EA, Meur G, Rutter GA: Glucose regulates free cytosolic $\mathrm{Zn}(2)$ concentration, Slc39 (ZiP), and metallothionein gene expression in primary pancreatic islet beta-cells. J Biol Chem 2011, 286(29):25778-25789.

25. Devergnas S, Chimienti F, Naud N, Pennequin A, Coquerel Y, Chantegrel J, Favier A, Seve M: Differential regulation of zinc efflux transporters ZnT-1, ZnT-5 and ZnT-7 gene expression by zinc levels: a real-time RT-PCR study. Biochem Pharmacol 2004, 68(4):699-709.

26. Staiger H, Machicao F, Schafer SA, Kirchhoff K, Kantartzis K, Guthoff M, Silbernagel G, Stefan N, Haring HU, Fritsche A: Polymorphisms within the novel type 2 diabetes risk locus MTNR1B determine beta-cell function. Plos One 2008, 3(12):e3962.

27. Kirchhoff K, Machicao F, Haupt A, Schafer SA, Tschritter O, Staiger H, Stefan $\mathrm{N}$, Haring HU, Fritsche A: Polymorphisms in the TCF7L2, CDKAL1 and SLC30A8 genes are associated with impaired proinsulin conversion. Diabetologia 2008, 51(4):597-601.

28. Sladek R, Rocheleau G, Rung J, Dina C, Shen L, Serre D, Boutin P, Vincent D, Belisle A, Hadjadj S, et al: A genome-wide association study identifies novel risk loci for type 2 diabetes. Nature 2007, 445(7130):881-885.

29. Saxena R, Voight BF, Lyssenko V, Burtt NP, de Bakker PI, Chen H, Roix JJ, Kathiresan S, Hirschhorn JN, Daly MJ, et al: Genome-wide association analysis identifies loci for type 2 diabetes and triglyceride levels. Science (New York, NY) 2007, 316(5829):1331-1336.

30. Chen H, Carlson EC, Pellet L, Moritz JT, Epstein PN: Overexpression of metallothionein in pancreatic beta-cells reduces streptozotocin-induced DNA damage and diabetes. Diabetes 2001, 50(9):2040-2046.

31. Li X, Chen H, Epstein PN: Metallothionein protects islets from hypoxia and extends islet graft survival by scavenging most kinds of reactive oxygen species. J Biol Chem 2004, 279(1):765-771.

32. Cai L: Metallothionein as an adaptive protein prevents diabetes and its toxicity. Nonlinearity Biol Toxicol Med 2004, 2(2):89-103.

33. Yang L, Li H, Yu T, Zhao H, Cherian MG, Cai L, Liu Y: Polymorphisms in metallothionein-1 and -2 genes associated with the risk of type 2 diabetes mellitus and its complications. Am J Physiol Endocrinol Metab 2008, 294(5):E987-E992.

34. Giacconi R, Bonfigli AR, Testa R, Sirolla C, Cipriano C, Marra M, Muti E, Malavolta M, Costarelli L, Piacenza F, et al: +647 A/C and +1245 MT1A polymorphisms in the susceptibility of diabetes mellitus and cardiovascular complications. Mol Genet Metab 2008, 94(1):98-104.

35. Merglen A, Theander S, Rubi B, Chaffard G, Wollheim CB, Maechler P: Glucose sensitivity and metabolism-secretion coupling studied during two-year continuous culture in INS-1E insulinoma cells. Endocrinology 2004, 145(2):667-678.

36. Asfari M, Janjic D, Meda P, Li G, Halban PA, Wollheim CB: Establishment of 2-mercaptoethanol-dependent differentiated insulin-secreting cell lines. Endocrinology 1992, 130(1):167-178

37. Vandesompele J, De Preter K, Pattyn F, Poppe B, Van Roy N, De Paepe A, Speleman F: Accurate normalization of real-time quantitative RT-PCR data by geometric averaging of multiple internal control genes. Genome Biol 2002, 3(7):RESEARCH0034.

38. Smidt K, Wogensen L, Brock B, Schmitz O, Rungby J: Real-time PCR: housekeeping genes in the INS-1E beta-cell line. Horm Metab Res 2006, 38(1):8-11.

39. Sensi SL, Jeng JM: Rethinking the excitotoxic ionic milieu: the emerging role of $\mathrm{Zn}(2+)$ in ischemic neuronal injury. Curr Mol Med 2004, 4(2):87-111.

40. Foster MC, Leapman RD, Li MX, Atwater I: Elemental composition of secretory granules in pancreatic islets of Langerhans. Biophys J 1993, 64(2):525-532

41. Hutton JC, Penn EJ, Peshavaria M: Low-molecular-weight constituents of isolated insulin-secretory granules. Bivalent cations, adenine nucleotides and inorganic phosphate. Biochem J 1983, 210(2):297-305.

42. Mathis $D$, Vence $L$, Benoist $C$ : beta-Cell death during progression to diabetes. Nature 2001, 414(6865):792-798.

43. Sheline CT, Shi C, Takata T, Zhu J, Zhang W, Sheline PJ, Cai AL, Li L: Dietary zinc reduction, pyruvate supplementation, or zinc transporter 5 knockout attenuates beta-cell death in nonobese diabetic mice, islets, and insulinoma cells. J Nutr 2012, 142(12):2119-2127.

44. Priel T, Aricha-Tamir B, Sekler I: Clioquinol attenuates zinc-dependent beta-cell death and the onset of insulitis and hyperglycemia associated with experimental type I diabetes in mice. Eur J Pharmacol 2007, 565(1-3):232-239.

45. Krezel A, Maret W: Thionein/metallothionein control Zn(II) availability and the activity of enzymes. J Biol Inorg Chem 2008, 13(3):401-409.

46. Heuchel R, Radtke F, Georgiev O, Stark G, Aguet M, Schaffner W: The transcription factor MTF-1 is essential for basal and heavy metal-induced metallothionein gene expression. EMBO J 1994, 13(12):2870-2875.

47. Meloni G, Sonois V, Delaine T, Guilloreau L, Gillet A, Teissie J, Faller P, Vasak M: Metal swap between Zn7-metallothionein-3 and amyloid-beta-Cu protects against amyloid-beta toxicity. Nat Chem Biol 2008, 4(6):366-372.

48. Hozumi I, Suzuki JS, Kanazawa H, Hara A, Saio M, Inuzuka T, Miyairi S, Naganuma A, Tohyama C: Metallothionein-3 is expressed in the brain and various peripheral organs of the rat. Neurosci Lett 2008, 438(1):54-58.

49. Smidt K, Rungby J: ZnT3: a zinc transporter active in several organs. Biometals 2012, 25(1):1-8

50. Palmiter RD, Cole TB, Quaife CJ, Findley SD: ZnT-3, a putative transporter of zinc into synaptic vesicles. Proc Natl Acad Sci U S A 1996, 93(25):14934-14939.

51. Leung KW, Liu M, Xu X, Seiler MJ, Barnstable CJ, Tombran-Tink J: Expression of ZnT and ZIP zinc transporters in the human RPE and their regulation by neurotrophic factors. Invest Ophthalmol Vis Sci 2008, 49(3):1221-1231.

52. Chimienti F, Devergnas S, Favier A, Seve M: Identification and cloning of a beta-cell-specific zinc transporter, ZnT-8, localized into insulin secretory granules. Diabetes 2004, 53(9):2330-2337.

53. Nigam PK: Serum zinc and copper levels and $\mathrm{Cu}: \mathrm{Zn}$ ratio in psoriasis. Indian J Dermatol Venereol Leprol 2005, 71(3):205-206.

54. Lowe NM, Bremner I, Jackson MJ: Plasma 65Zn kinetics in the rat. Br J Nutr 1991, 65(3):445-455.

55. Richards-Williams C, Contreras JL, Berecek KH, Schwiebert EM: Extracellular ATP and zinc are co-secreted with insulin and activate multiple P2X purinergic receptor channels expressed by islet beta-cells to potentiate insulin secretion. Purinergic Signal 2008, 4(4):393-405.

56. Lavoie N, Peralta MR, Chiasson M, Lafortune K, Pellegrini L, Seress L, Tóth K Extracellular chelation of zinc does not affect hippocampal excitability and seizure-induced cell death in rats. J Physio/ 2007, 578(1):275-289.

57. Shumaker DK, Vann LR, Goldberg MW, Allen TD, Wilson KL: TPEN, a Zn2+/ $\mathrm{Fe} 2+$ chelator with low affinity for $\mathrm{Ca} 2+$, inhibits lamin assembly, destabilizes nuclear architecture and may independently protect nuclei from apoptosis in vitro. Cell Calcium 1998, 23(2-3):151-164.

58. Kay AR, Toth K: Is zinc a neuromodulator? Sci Signal 2008, 1(19):re3.

59. Albert B, Johnson A, Lewis J, Raff M, Roberts K, Walter P: Molecular Biology of The Cell, Garland Science. 5th edition. ; 2008:501-505. 544-546.

60. Huang L, Yan M, Kirschke CP: Over-expression of ZnT7 increases insulin synthesis and secretion in pancreatic beta-cells by promoting insulin gene transcription. Exp Cell Res 2010, 316(16):2630-2643. 
61. Chesters JK, Boyne R: Nature of the $\mathrm{Zn2}+$ requirement for DNA synthesis by 3 T3 cells. Exp Cell Res 1991, 192(2):631-634.

62. MacDonald RS: The role of zinc in growth and cell proliferation. J Nutr 2000, 130(5S Suppl):1500S-1508S

63. Jackson KA, Helston RM, McKay JA, O'Neill ED, Mathers JC, Ford D: Splice variants of the human zinc transporter ZnT5 (SLC30A5) are differentially localized and regulated by zinc through transcription and mRNA stability. J Biol Chem 2007, 282(14):10423-10431.

64. Valentine RA, Jackson KA, Christie GR, Mathers JC, Taylor PM, Ford D: ZnT5 variant $\mathrm{B}$ is a bidirectional zinc transporter and mediates zinc uptake in human intestinal Caco-2 cells. J Biol Chem 2007, 282(19):14389-14393.

65. Kambe T, Narita H, Yamaguchi-Iwai Y, Hirose J, Amano T, Sugiura N, Sasaki R, Mori K, Iwanaga T, Nagao M: Cloning and characterization of a novel mammalian zinc transporter, zinc transporter 5 , abundantly expressed in pancreatic beta cells. J Biol Chem 2002, 277(21):19049-19055.

doi:10.1186/1756-0500-7-84

Cite this article as: Nygaard et al.: Effects of zinc supplementation and zinc chelation on in vitro $\beta$-cell function in INS-1E cells. BMC Research Notes 2014 7:84.

\section{Submit your next manuscript to BioMed Central and take full advantage of:}

- Convenient online submission

- Thorough peer review

- No space constraints or color figure charges

- Immediate publication on acceptance

- Inclusion in PubMed, CAS, Scopus and Google Scholar

- Research which is freely available for redistribution 